\title{
Profile of Herpes Zoster Patients with Co-morbidities: Cross-sectional Observation at a Tertiary Level Hospital in Dhaka
}

\author{
Khan $\mathrm{MSI}^{1}$, Emran $\mathrm{HM}^{2}$, Karim $\mathrm{ATMR}^{3}$ \\ DOl:https://doi.org/10.3329/jafmc.v16i2.55296
}

\begin{abstract}
Introduction: Herpes zoster $(\mathrm{HZ})$ is characterized by an extremely painful vesicular rash, which may be complicated by secondary infection and post-herpetic neuralgia. To date, multiple risk factors associated with $\mathrm{HZ}$ have been established, including endocrine diseases, immunosuppressive conditions, cancers, and other chronic medical conditions.
\end{abstract}

Objectives: To assess the profile of herpes zoster associated with co-morbid condition.

Methods and Materials: This cross sectional study was conducted among purposively selected $130 \mathrm{HZ}$ patients in the department of Dermatology and Venereology, Combined Military Hospital (CMH) Dhaka from January 2017 to December 2018. Data were collected through face to face interview using pretested semi-structured questionnaire.

Results: Out of 130 patients, majority of the patients were male $(69.2 \%)$ and mean age was $53.5 \pm 9.8$ years and majority gave the history of chicken pox $60 \%$ and common site of involvement were chest (right and left) $33.1 \%$ and $48.5 \%$, upper back (right and left) $30.8 \%$ and $43.1 \%$ and upper right arm $33.1 \%$. About $66.9 \%$ patients gave the history of having co-morbid condition like Diabetes $30.8 \%$, Stroke 9.2\%, Hypertension 2.3\%, Myocardial infarction $3.8 \%$, Peptic ulcer disease $10.0 \%$, Malignancy $2.3 \%$, Tuberculosis 2.3\% and Irritable bowel syndrome 2.3\%.

Conclusion: Based on our study finding, we can conclude that herpes zoster is a disease that is associated with other co-morbid conditions. If herpes zoster is an early manifestation of undiagnosed co-morbid condition, patients should undergo testing for undiagnosed disease when they present with herpes zoster.

Key-words: Herpes zoster, Herpes zoster with co-morbidities.

\section{Introduction}

Varicella zoster virus (VZV) has been described as a "re-emerging" infection because of its potentially increased prevalence as elderly and immunocompromised populations grow in modern societies.
Herpes zoster $(\mathrm{HZ})$ is caused by the reactivation of VZV latent in the sensory ganglia after primary infection. It is a painful blister or rash on the affected dermatomes secondary to the spreading of the virus along the sensory nerve fibers ${ }^{1-3}$. The occurrence of herpes zoster could be associated with derangement of the immunological status of hosts related to aging, trauma, stress, or other diseases ${ }^{4}$. The incidence of $\mathrm{HZ}$ substantially increases with age and immunosuppression ${ }^{5}$. Other risk factors include human immunodeficiency virus infection, neoplastic diseases, organ transplantation, use of immunosuppressive drugs, and other conditions that cause a decline in cell-mediated immunity ${ }^{6,7}$.

Diabetic patients are susceptible to $\mathrm{HZ}$ secondary to $\mathrm{VZV}$ reactivation as cell-mediated immunity (CMI) declines during the process ${ }^{8}$. Certain drugs which are commonly used in diabetes and related conditions are thought to increase the risk of $\mathrm{HZ}^{9}$. When patients have two or more coexisting co-morbidities, there is an increased risk of $\mathrm{HZ}$ occurrence10. Numerous reports of VZV-induced vasculopathy and stroke syndrome after herpes zoster attacks have been reported since the early 1970 s. VZV is also the only recognized human virus able to replicate in cerebral arteries ${ }^{11,12}$. Some studies have also revealed that herpes zoster could be an early manifestation of undiagnosed HIV infection because of an early defect in cell-mediated immunity ${ }^{13,14}$. Cancer patients may experience cell-mediated immunosuppression, resulting from chemotherapy, psychological stress, or physical trauma of surgery or radiotherapy, putting them at greater risk of herpes zoster ${ }^{15}$.A wide spectrum of neurological consequences of VZV reactivation, such as postherpetic neuralgia, associated neuropathy, radiculitis, myelitis, encephalitis, ventriculitis, vasculopathy, Guillain-Barré syndrome (GBS), Parkinson's disease and stroke, have been recognized ${ }^{16-18}$. To date, no formal research based on systematic analysis has focused on the relationship between $\mathrm{HZ}$ and co-morbid condition. As such the present study aimed to assess the profile of $\mathrm{HZ}$ patient associated with various co-morbidities.

\section{Methods and Materials}

This cross sectional study was conducted at the department of Dermatology and Venerology of Combined Military Hospital Dhaka from January 2017 to December 2018. Irrespective of age and sex,

1. Col Md Shirajul Islam Khan, MBBS, DDV, MCPS, FCPS, Classified Specialist in Dermatology and Venereology, CMH, Dhaka (E-mail: siraj824@gmail.com) 2. Maj Hossain Md Emran, MBBS, DDV Graded specialist in Dermatology and Venereology, CMH, Dhaka 3. Lt Col ATM Rezaul Karim, MBBS, MCPS, DDV, FCPS, Associate Professor \& Head, Department of Dermatology, AFMC, Dhaka 
diagnosed $130 \mathrm{HZ}$ patients were selected purposively with an objective to assess the profile of $\mathrm{HZ}$ associated with co-morbid condition. Prior to conduct the study ethical clearance was taken from Ethical Committee of $\mathrm{CMH}$ Dhaka. Data were collected through face-to-face interview with the help of pretested semi-structured questionnaire and checklist. Informed written consent was taken from all the respondents and neither any intervention nor any invasive procedure was undertaken. The questionnaire included the sociodemographic, $\mathrm{HZ}$ related information and details about the co-morbidities related to $\mathrm{HZ}$. Data processing and analyses were done using Statistical Package for Social Sciences (SPSS) software.

\section{Results}

Among $130 \mathrm{HZ}$ patients, the majority (69.2\%) were males. The majority (48.5\%) of the patients were in the age group $>50$ years, $33.1 \%$ belonged to the age group 41-50 years and their mean age $( \pm S D)$ was $53.5 \pm 9.8$ years. Of all, $87.7 \%$ were from armed forces personnel which was followed by house wife (8.5\%) (Table-I). The majority (60\%) gave the history of chicken pox and common site of involvement were chest (right $33.1 \%$ and left $48.5 \%$,) and upper back (right $30.8 \%$ and left $43.1 \%$ ) and upper right arm 33.1\% (Table-II). Out of 130 patients about $66.9 \%$ patients gave the history of having co-morbid condition like Diabetes $30.8 \%$, Stroke 9.2\%, Hypertension 2.3\%, myocardial infarction 3.8\%, Peptic ulcer disease $10.0 \%$, malignancy $2.3 \%$, tuberculosis $2.3 \%$, history of radiotherapy $2.3 \%$, and irritable bowel syndrome $2.3 \%$ (Table-III).

Table-I: Socio-demographic characteristics of the study patients $(n=130)$

\begin{tabular}{|l|c|}
\hline Characteristics & Frequency (\%) \\
\hline Sex & $90(69.2)$ \\
\hline Male & $40(30.8)$ \\
\hline Female & $2(1.5)$ \\
\hline Age in years & $9(6.9)$ \\
\hline$\leq 20$ & $13(10)$ \\
\hline $21-30$ & $43(33.1)$ \\
\hline $31-40$ & $63(48.5)$ \\
\hline $41-50$ & \\
\hline$>50$ & \\
\hline \multicolumn{2}{|c|}{ Mean age $\pm S D=53.45 \pm 9.77$} \\
\hline Occupational status & $114(87.7)$ \\
\hline Armed forces personnel & $11(8.5)$ \\
\hline House wife & $3(2.3)$ \\
\hline Student & $1(0.8)$ \\
\hline Messenger & $1(0.8)$ \\
\hline Cook &
\end{tabular}

Table-II: Distribution of the patients by clinical characteristics $(n=130)$

\begin{tabular}{|l|c|}
\hline Characteristics & Frequency (\%) \\
\hline History of chicken pox & $78(60)$ \\
\hline Yes & $52(40)$ \\
\hline No & \\
\hline Site of involvement & $63(48.5)$ \\
\hline Chest (Left side) & $43(33.1)$ \\
\hline Chest (right side) & $15(11.5)$ \\
\hline Forehead (left side) & $11(8.5)$ \\
\hline Forehead (right side) & $13(10.0)$ \\
\hline Nose (Left side) & $9(6.9)$ \\
\hline Neck (right side) & $12(9.2)$ \\
\hline Forearm (right) & $40(30.8)$ \\
\hline Upper back (right side) & $56(43.1)$ \\
\hline Upper back (left side) & $31(23.0)$ \\
\hline Lower back (right side) & $19(14.6)$ \\
\hline Lower back (left side) & $5(3.8)$ \\
\hline Scalp (right side) & $43(33.1)$ \\
\hline Upper arm (right) & $6(4.6)$ \\
\hline shoulder (left) & $13(10.0)$ \\
\hline shoulder (right) & $11(8.5)$ \\
\hline Buttock and thigh (right side) & \\
\hline
\end{tabular}

Table-III: Distribution of the patients of herpes zoster by co-morbidities ( $\mathrm{n}=130$ )

\begin{tabular}{|l|c|}
\hline Co-morbidities & Frequency (\%) \\
\hline History of co-morbidity & \\
\hline Yes & $87(66.9)$ \\
\hline No & $43(33.1)$ \\
\hline Co-morbid conditions & \\
\hline Diabetes & $40(30.8)$ \\
\hline Stroke & $12(9.2)$ \\
\hline Hypertension & $3(2.3)$ \\
\hline Myocardial infarction & $5(3.8)$ \\
\hline Malignancy & $1(2.3)$ \\
\hline Tuberculosis & $1(2.3)$ \\
\hline Radiotherapy & $1(2.3)$ \\
\hline Peptic ulcer disease & $13(10.0)$ \\
\hline Irritable bowel syndrome & $1(2.3)$ \\
\hline
\end{tabular}

\section{Discussion}

We conducted this single centered cross sectional study to assess the profile of $\mathrm{HZ}$ patients associated with co-morbid condition. We took the diagnosed case of $\mathrm{HZ}$ patients utilizing standard case definition. Major co-morbidities identified include diabetes, peptic ulcer disease, stroke, myocardial infarction. The study results will helps to take comprehensive preventive measures against $\mathrm{HZ}$.

We revealed that male (69.2\%) were more affected with $\mathrm{HZ}$ than female which is consistent with the findings of Oxman MN et al ${ }^{2}$ but 
dissimilar with the findings of Esteban-Vasallo MD et al and Breuer $\mathrm{J}$ et al. ${ }^{4}{ }_{11}$ which is may be due to the fact that majority of the respondents in our study were from serving armed forces personnel. Our study revealed that the majority (48.5\%) of the patients were in the age group $>50$ years, and $33.1 \%$ belonged to the age group $41-50$ years and $30.8 \%$ of the respondents had diabetes as co-morbidity. According to the demographic profile of Bangladesh, the majority $(40.07 \%)$ of the population belong to the age group of $25-54$ years, and $6.42 \%$ belong to the age group $>65$ years $^{19}$. Though the majority of patients belonged to the middle age group, but in our study the majority patients were advanced age group (>51 years) which is consistent with the study conducted by Ke CC et al., who conducted a case-control study from 2005 to 2011 in Taiwan which included 25, 345 newly diagnosed herpes zoster patients as case in a 1:4 ratio with control. They revealed that the highest rate in patients $>70$ years old and the lowest rate in those $<30$ years old. Both male and female diabetic patients appeared to have an increased risk of developing herpes zoster compared to those without diabetes respectively. They also revealed that patients with DM were associated with a $24 \%$ increase in the risk of $\mathrm{HZ}$ as compared to those without diabetes $(\mathrm{OR}=1.24,95 \% \mathrm{Cl}=$ 1.19-1.28, $p<0.001)$. They found that diabetic patients co-morbid with coronary artery disease (CAD) alone had a significantly higher risk of developing $\mathrm{HZ}$ than patients without $\mathrm{CAD}(21.2 \%$ vs. $18.5 \%$, adjusted $\mathrm{OR}=1.21,95 \% \mathrm{Cl}=1.12-1.31, \mathrm{p}<0.001)$. Regarding the combination of complications associated with the risk of $\mathrm{HZ}$, diabetic patients co-morbid with both CAD and microvascular diseases had the highest risk (OR $=1.32,95 \% \mathrm{Cl}=1.12-1.55, \mathrm{p}<0.001)$, as compared to those without CAD or microvascular diseases ${ }^{20}$. Naveen $\mathrm{KN}$ et al. found in their study that the majority of the patients were in the third decade which is not similar to our study3. By occupation, lion shareholders were service holders (87.7\%). As the study was conducted at $\mathrm{CMH}$ Dhaka where only the entitled serving and retired armed forces personnel including their family members get the treatment so it is obvious that the majority of the respondents should be the service holders. In regards to the distribution of the rash of $\mathrm{HZ}$, we found common site were at the chest which is consistent with the findings of Weinberg $\mathrm{JM}^{10}$.

In regards to the co-morbidities, the majority (30.8\%) of the respondents had diabetes mellitus which was followed by peptic ulcer disease (10.0\%) and stroke (9.2\%). These findings were almost similar to the findings of Guignard AP et al, Struijs JN et al and Hansson et al $\mathrm{a}^{8,9,21}$.

\section{Conclusion}

Based on the study findings, majority of the herpes zoster patients gave the history of having co-morbid conditions. Among the herpes zoster patients, diabetes was the highest, next was peptic ulcer disease, stroke, myocardial infarction, malignancy, tuberculosis, hypertension and irritable bowel syndrome. If herpes zoster is an early manifestation of undiagnosed co-morbid condition, patients should undergo testing for undiagnosed disease when they present with herpes zoster.

\section{References}

1. Cohen Jl. Clinical practice: Herpes zoster. N Engl J Med. 2013; 369:255-63.

2. Oxman $M N$, Levin $M J$, Johnson $G R$ et al. A vaccine to prevent herpes zoster and postherpetic neuralgia in older adults. N Engl J Med. 2005; 352(22):2271-84.

3. Naveen KN, Tophakane RS, Hanumanthayya K et al. A study of HIV seropositivity with various clinical manifestation of herpes zoster among patients from Karnataka, India. Dermatol Online J. 2011; 17(12):3.

4. Esteban-Vasallo MD, Domínguez-Berjón MF, Gil-Prieto R et al. Sociodemographic characteristics and chronic medical conditions as risk factors for herpes zoster: A population-based study from primary care in Madrid (Spain). Human Vaccines \& Immunotherapeutics. 2014; 10(6):1650-60.

5. Kawai K, Gebremeskel BG, Acosta CJ. Systematic review of incidence and complications of herpes zoster: Towards a global perspective. BMJ Open. 2014; 4(6):e004833.

6. Wung PK, Holbrook JT, Hoffman GS et al. Herpes zoster in immunocompromised patients: Incidence, timing and risk factors. The American Journal of Medicine. 2005; 118(12):1416-e9.

7. DeLaGarza VW, Arbogast JG, Podolinski CF et al. Reactivation of herpes zoster (shingles) infection associated with an increased risk of death in immunocompetent older persons. West Virginia Medical Journal. 2008; 104(5):22-5.

8. Guignard AP, Greenberg M, Lu C et al. Risk of herpes zoster among diabetics: A matched cohort study in a US insurance claim database before introduction of vaccination, 1997-2006. Infection. 2014; 42(4):729-35.

9. Struijs JN, Baan CA, Schellevis FG et al. Comorbidity in patients with diabetes mellitus: Impact on medical health care utilization. BMC health Services Research. 2006; 6(1):1-9.

10. Weinberg JM. Herpes zoster: Epidemiology, natural history and common complications. Journal of the American Academy of Dermatology. 2007; 57(6):S130-5.

11. Breuer J, Pacou M, Gautier A et al. Herpes zoster as a risk factor for stroke and TIA: A retrospective cohort study in the UK. Neurology. 2014; 83(2):e27-33.

12. Kang JH, Ho JD, Chen YH et al. Increased risk of stroke after a herpes zoster attack: A population-based follow-up study. Stroke. 2009; 40(11):3443-8.

13. Sharvadze L, Tsertsvadze T, Gochitashvili N et al. HIV prevalence among high risk behavior group persons with herpes zoster infection. Georgian Med News. 2006; 132:60-4.

14. Joesoef RM, Harpaz R, Leung J et al. Chronic medical conditions as risk factors for herpes zoster. In Mayo Clinic Proceedings. 2012; 87(10):961-7.

15. Attal N, Deback C, Gavazzi G et al. Herpes Zoster and Functional 
Decline Consortium, Pickering G, Schmader K. Functional decline and herpes zoster in older people: An interplay of multiple factors. Aging Clin Exp Res. 2015; 27(6):757-65.

16. Lee JK, Tran T, Tansey MG. Neuroinflammation in Parkinson's disease. Journal of Neuroimmune Pharmacology. 2009; 4(4):419-29.

17. Qian L, Flood PM, Hong JS. Neuroinflammation is a key player in Parkinson's disease and a prime target for therapy. Journal of Neural Transmission. 2010; 117(8):971-9.

18. Joers V, Tansey MG, Mulas $G$ et al. Microglial phenotypes in Parkinson's disease and animal models of the disease. Progress in neurobiology. 2017; 155:57-75.
19. $\mathrm{Ke} \mathrm{CC}$, Lai HC, Lin $\mathrm{CH}$ et al. Increased risk of herpes zoster in diabetic patient's comorbid with coronary artery disease and microvascular disorders: A population-based study in Taiwan. PLoS One. 2016; 11(1):e0146750.

20. Hansson E, Forbes HJ, Langan SM et al. Herpes zoster risk after 21 specific cancers: population-based case-control study. British journal of cancer. 2017; 116(12):1643-51.

21. Central Intelligence Agency. Bangladesh Demographic Profile (BDP) 2019. The world fact book, 2019. https://www.cia.gov/ library/publications/the-world-factbook/geos/bg.html (Accessed 16 September 2020). 